\title{
Pengembangan dan Manajemen Badan Usaha Milik Desa di Desa Tiwoho Kecamatan Wori Kabupaten Minahasa Utara
}

\author{
Jeane Mantiri*, Margareth Rantung a, ${ }^{\text {* }}$ \\ ${ }^{a}$ Universitas Negeri Manado, Prodi Ilmu Administrasi Negara, Manado, Indonesia \\ ${ }^{1}$ jeanelitha@unima.ac.id *; ${ }^{2}$ margarethrantung@unima.ac.id
}

IN F O A R T I K E

\section{Key word:}

BUMDes,

Tiwoho Village,

DanaeVillage,

Regional Economy

\section{A B S T R A C T}

The purpose of this study is to find out how the development and management of BUMDES in Tiwoho Village, Wori District, North Minahasa and produces; 1). In establishing Village Owned Enterprises (BUMDes) Planning certainly plays an important role so that in planning there are business objectives, procedures and programs that are formed; 2). The organization must be outside the organizational structure of the village government, because the Tiwoho Village BUMDes only has three administrators since the Village Owned Enterprises (BUMDes) were established in Tiwoho Village; 3). In the term of mobilization with VillageOwned Enterprises (BUMDes) there is always guidance, suggestions and orders from the management of the Village-Owned Enterprises by providing guidance, suggestions so that they can work optimally and placing orders on task applications in order to achieve the predetermined goals; 4). In terms of supervision, according to the central supervisory members, according to the village government, there is still a lack of involvement in the supervision of Tiwoho Village-Owned Enterprises, in terms of supervision, it is still low.

\section{INTISARI}

\section{Kata kunci:}

BUMDES,

Desa Tiwoho,

Dana Desa,

Perekonomian Daerah
Tujuan dari penelitian ini adah untuk mengetahui Bagaimana Pengembangan dan Manajemen BUMDES di Desa Tiwoho Kecamatan Wori Kabupaten Minahasa Utara dengan menggunakan metode penelitian Focus Group Discussion hasil penelitian ini adalah; 1). Dalam mendirikan Badan Usaha Milik Desa (BUMDes)Perencanaan tentunya memegang peran penting sehingga didalam perencanaan ada tujuan usaha, prosedur dan program yang dibentuk; 2). Organisasi harus berada di luar struktur organisasi pemerintahan desa, karena BUMDes Desa Tiwoho hanya memiliki tiga pengurus sejak Badan Usaha Milik Desa (BUMDes) didirikan di Desa Tiwoho; 3). Pada termin penggerakan dengan Badan Usaha Milik Desa (BUMDes) selalu adanya bimbingan, saran \& perintah menurut pengurus Badan Usaha Milik Desa menggunakan menaruh bimbingan, saran supaya sanggup bekerja secara optimal dan menaruh perintah pada aplikasi tugas supaya bisa mencapai tujuan yg sudah ditentukan; 4). Pada termin supervisi masih kurangnya keterlibatan menurut anggota pengawas sentra menurut pemerintah desa bahkan warga pada mengawasi Badan Usaha Milik Desa Tiwoho dalam termin supervisi masih rendah. 


\section{Pendahuluan}

\subsection{Latar Belakang dan Permasalahan}

Desa adalah bagian yang paling kecil dari suatu negara juga merupakan bidang yang paling dekat dengan masyarakat dan bersentuhan langsung dengan kesejahteraan masyarakat. Dasar dari sistem sosial yang kuat di desa adalah kekuatan untuk pembangunan politik, sosial, budaya dan ekonomi. lebih dari 32.000 Desa tergolong Desa terbelakang dari banyaknya 74.093 Desa di Indonesia. Kondisi ini bertentangan dengan tujuan otonomi daerah [1].

Badan Usaha Milik Desa (BUMDes) merupakan instrumen pembangunan ekonomi daerah dengan jenis perusahaan yang berbeda-beda tergantung potensi desa. Membuka potensi ini bertujuan untuk meningkatkan kesejahteraan ekonomi masyarakat pedesaan melalui pengembangan usaha bisnis. PAD), yang memungkinkan masyarakat untuk melaksanakan pembangunan dan kesejahteraan secara optimal [2].

BUMDes sebenarnya adalah lembaga sosial yang telah menyelaraskan diri dengan kepentingan masyarakat melalui kontribusinya sebagai penyedia layanan sosial. Namun, BUMDes juga merupakan lembaga komersial di mana BUMDes berusaha mencari keuntungan dengan menjual barang atau jasa yang ditujukan untuk masyarakat. dan sesuai dengan aturan yang berlaku di desa. Dalam UndangUndang Nomor 32 Tahun 2004 tentang Pemerintah Daerah, Pasal 213 (13) mengatur bahwa desa dapat mendirikan Badan Usaha Milik Desa (BUMDes) sesuai dengan kebutuhan dan potensi desa. Menurut peraturan ini, pendirian BUMDes didasarkan pada kebutuhan dan potensi kota dengan tujuan untuk meningkatkan kesejahteraan masyarakat [3]. Dalam hal ini perencanaan dan pembentukan, BUMDes dibangun atas prakarsa masyarakat desa, dan berlandaskan prinsip kooperatif, partisipatif, dan emansipatoris. Yang terpenting pengelolaan BUMDes harus dilakukan secara profesional, kooperatif, dan mandiri. Dengan demikian, membangun BUMDes bisa berbeda-beda di setiap desa di Indonesia. Sehubungan dengan hal tersebut, untuk membangun BUMDes diperlukan informasi yang akurat dan tepat mengenai karakteristik lokal termasuk karakteristik sosial budaya masyarakat [4].

Melihat posisi BUMDes dalam menghadapi realita mendesaknya arus intervensi modal dalam dan luar negeri yang kini menjadikan desa sasaran pengembangan usaha sangat sulit, selain itu BUMDes ini hanya bermodal kecil jika dibandingkan dengan swasta. sektor yang selalu bermodal besar. Dengan sumber daya alam yang dimiliki desa, hal ini sangat rentan terhadap intervensi pasar modal di pedesaan. Kehadiran BUMDes sendiri akan menjadi penangkal kekuatan korporasi asing maupun nasional. BUMDes ini diharapkan mampu menggerakkan dinamika perekonomian desa, dan menjadi Badan Usaha Milik
Desa [5].

Jika hampir separuh desa di Indonesia masih tergolong desa tertinggal, maka tidak mengherankan jika hingga saat ini desa tersebut masih identik dengan kemiskinan dan ketertinggalan. Terbitnya Undang-Undang Nomor 6 Tahun 2014 tentang Desa membayangkan kehidupan desa yang otonom dalam mengurus pemerintahan dan masyarakat [2]. Dalam Peraturan Pemerintah Nomor 43 Tahun 2014 sebagaimana telah diubah dengan Peraturan Pemerintah Nomor 47 Tahun 2015 disebutkan bahwa saat ini desa memiliki kewenangan untuk mengatur sumber daya dan arah pembangunan. Oleh karena itu, dinamika dasar kehidupan desa sangat bergantung pada partisipasi masyarakat dalam mendorong terbentuknya kesepakatan pengelolaan desa, mampu membina dan mengembangkan nilainilai sosial, budaya, ekonomi dan pengetahuan. Diberlakukannya perdes membuka harapan bagi masyarakat desa untuk berubah. Ini menjadi momentum untuk mendorong lahirnya desa dengan pemerintahan yang lebih akuntabel dan transparan, masyarakat desa yang partisipatif, dan ekonomi desa yang suportif [6].

Penyelenggaraan pemerintahan desa diatur dalam Undang-Undang Nomor 6 Tahun 2014 tentang Desa. Pelaksanaan kegiatan penelitian ini didasarkan pada fenomena yang terjadi yaitu minimnya program kegiatan pemberdayaan masyarakat dan rendahnya tingkat ekonomi masyarakat Desa Tiwoho karena masyarakat Desa Tiwoho rata-rata berprofesi sebagai petani, buruh tani, buruh dan buruh kecil. pedagang serta penganggur yang masih dalam usia produktif, diharapkan Keberadaan BUM Desa mampu mendorong dinamika kehidupan ekonomi sekaligus sebagai penggerak perekonomian masyarakat desa dan diharapkan dapat meningkatkan kesejahteraan masyarakat desa. masyarakat desa, dan dapat membentuk kelembagaan struktur BUMDes di Desa Tiwoho, hal ini sejalan dengan PMDes No.4 Tahun 2015 bahwa: Adanya BUMDes untuk pengembangan daerah tertinggal dan transmigrasi, tentang pembentukan, pengelolaan \& pengelolaan, dan pembubaran BUMDes [7].

Efektifnya pelaksanaan BUMDes diharapkan untuk dapat memajukan desa dan menjadikan masyarakat desa yang sejahtera, melalui keaktifan lembaga desa dan terlaksananya tujuan serta program desa. Hal ini sesuai dengan pendapat Djafri, yang menyatakan bahwa "Efektivitas adalah usaha kepemimpinan melalui sistem managerial yang dicapai secara terukur untuk mencapai tujuan organisasi dalam arti tercapainya tujuan yang telah ditentukan sebelumnya melalui fungsi manajemen". Dalam pengelolaan badan usaha milik desa berbasis kerakyatan masyarakat desa upaya mewujudkan pencapaian tujuan dalam organisasi maka 
masyarakat desa juga diperlukan sumber daya manusia masyarakat desa yang berkualitas mengerti dan paham aturan- aturan dan manajemen pengelolaan administrasi dan dananya [5].

Berdasarkan uraian diatas, judul penelitian ini adalah: "Pengembangan dan Manajemen BUMDES di Desa Tiwoho Kecamatan Wori Kabupaten Minahasa Utara

\subsection{Rumusan Masalah}

Berdasarkan latar belakan diatas maka rumusan masalah dari penelitian ini adalah:

Bagaimana Pengembangan dan Manajemen BUMDES di Desa Tiwoho Kecamatan Wori Kabupaten Minahasa Utara?"

\subsection{Tujuan Khusus}

Untuk Mengetahui Bagaimana Pengembangan dan Manajemen BUMDES di Desa Tiwoho Kecamatan Wori Kabupaten Minahasa Utara.

\section{Metode Penelitian}

\subsection{Metode/Konsep Yang Digunakan}

Metode yang digunakan adalah metode Focus Group Discussion (FGD), ceramah, dan partisipatif, serta latihan soal. Teknik pelaksanaan kegiatan yang digunakan berupa observasi, wawancara dan dokumentasi. Adapun pelaporan kegiatan meliputi: melalui analisis data lapangan, dokumentasi dan penarikan kesimpulan yang disajikan dalam laporan kegiatan. Kegiatan penelitian ini menggunakan pendekatan strategi sinergis sesuai dengan potensi dan penyelesaian masalah yang komprehensif meliputi tujuan, sasaran, ruang lingkup, koordinasi, komunikasi aktif, sasaran dan hasil. [7].

Bentuk pelaksanaan kegiatan penelitian dilakukan pendampingan antar perguruan tinggi; Anggota Tim Peneliti, Mahasiswa Universitas Negeri Manado, Perangkat Desa dan Masyarakat Desa Tiwoho, dengan rumusan kegiatannya;

(1) Pembentukan Administrasi kelembagaan BUMDes, melalui pelantikan pengurus BUMDes oleh pejabat yang berwenang

(2) FGD untuk pelatihan manajemen Profesi admistrasi, melalui Narasumber Ahli keilmuan bidang Manajemen \& Administrasi, dalam bentuk ceramah, diskusi dan dialog fokus. Adapun bentuk konsep materi pelatihan; pelatihan dalam bentuk Focus Group Discussion (FGD) untuk usaha yang sudah terbentuk dari awal BUMDes dapat di tingkatkan melalui;

(2.1) pelatihan peningkatan manajemen usaha desa, sebagai penguatan untuk pemberdayaan masyarakat dalam meningkatkan perekonomian usahanya, dengan tujuan memenej orang-orang yang berjiwa pengusaha (entrepreneur),
(2.2) Menjelaskan kepada masyarakat tentang keberadaan BUMDes, agar dapat membantu jenis usaha yang dapat di danai.

(2.3) Melatih ketrampilan masyarakat untuk peningkatan potensi usaha masyarakat di desa Tiwoho.

(3) Pelatihan usaha desa ini melalui kelompok partisipatif pendampingan terintegrasi, yang di petakan dalam 3 (tiga) kelompok kerja mahasiswa; yakni kelompok pertama; untuk Penataan Desa Tiwoho; kelembagaan, Perencanaan program dan implementasi program dan kelompok BUMDesa, serta Pengelolaan Anggaran yaitu: laporan akuntabilitas dan Transparansi pelaporan penggunaan anggaran. Kelompok, dua; FGD Pelatihan Manajemen Usaha Milik Desa, ketiga; Pelatihan Pemasaran dan Promosi Usaha, Melalui Informasi Teknologi. Capaian akhir kegiatan Penelitian ini adalah: Melalui Pelatihan Manajemen Usaha Milik Desa diharapkan dapat memberi Penguatan Pemberdayaan Desa Tiwoho melalui BUMDes dalam peningkatan Peran Kepala Desa untuk mencapai Tujuan, sasaran, program desa yang efektif, mandiri dan sejahtera

\subsection{Persiapan dan Desain Rancangan FGD}

1. Membentuk Tim

Tim FGD umumnya mencakup:

- Moderator, yaitu fasilitator diskusi yang terlatih dan memahami masalah yang dibahas serta tujuan penelitian yang hendak dicapai (ketrampilan substantif),

- Asisten Moderator/co-fasilitator, yaitu orang yang intensif mengamati jalannya FGD.

- $\quad$ Pencatat Proses/Notulen, yaitu orang bertugas mencatat inti permasalahan yang didiskusikan serta dinamika kelompoknya.

- $\quad$ Penyedia Logistik, yaitu orang-orang yang membantu kelancaran FGD berkaitan dengan penyediaan transportasi, kebutuhan rehat, konsumsi, akomodasi (jika diperlukan), insentif (bisa uang atau barang/cinderamata), alat dokumentasi, dll.

- Dokumentasi, yaitu orang yang mendokumentasikan kegiatan dan dokumen FGD: memotret, merekam (audio/video), dan menjamin berjalannya alat-alat dokumentasi, terutama perekam selama dan sesudah FGD berlangsung.

- Lain-lain jika diperlukan (tentatif), 


\section{Memilih dan mengatur tempat}

Pada prinsipnya, FGD dapat dilakukan di mana saja, namun sebaiknya tempat FGD yang dipilih hendaknya merupakan tempat yang netral, nyaman, aman, tidak bising, berventilasi cukup, dan bebas dari gangguan yang diperkirakan bisa muncul.

3. Menyiapkan Logistik

Logistik adalah berbagai

keperluan teknis yang dipelukan sebelum, selama, dan sesudah FGD terselenggara.

\subsection{Menyusun Pertanyaan FGD}

Agar pelaksanaan FGD berjalan lancar dan informasi yang di dapat sesuai dengan tujuan dari penelitian, diperlukan penyusunan pertanyaan/Guideline FGD. Tujuannya agar diskusi dapat berjalan terstruktur tidak keluar dari tujuan yang sudah ditentukan agar hasil dari FGD tersebut dapat merepresentasikan alasan, motivasi, tujuan dll yang berhubungan dengan topik/pembahasan yang di diskusikan [8].

\subsection{Pelaksanaan FGD}

Seperti yang sudah di jelaskan di awal bahwa dalam pelaksanaan FGD agar diskusi yang dilakukan berjalan baik (terarah/fokus, tidak ramai karena semua peserta ingin berbicara mengeluarkan pendapat, informasi dapat terjawab sesuai dengan harapan dan tujuan FGD) dibantu dengan seseorang yang dapat memfasilitatorkan para peserta lainnya yang dinamakan moderator.

Penelitian yang melibatkan hewan atau manusia, dan penelitian lain yang memerlukan persetujuan etis harus mencantumkan pihak yang memberikan persetujuan dan kode persetujuan etis yang sesuai.

\section{Hasil dan Pembahasan}

Pentingnya manajemen bagi keberhasilan organisasi yang dilaksanakan dan dapat terlaksana sesuai dengan tujuan awal yang ingin dicapai oleh suatu organisasi, dalam hal ini pelaksanaan pengelolaan Badan Usaha Milik Masyarakat (BUMDes) tidak berjalan sesuai dengan jawaban wawancara informan yang dilakukan. Untuk mengetahui reaksi para informan terhadap indikatorindikator tersebut di atas, penulis akan menjabarkan indikator-indikator tersebut secara lebih rinci seperti di bawah ini;

\subsection{Perencanaan (Planning)}

Perencanaan usaha pada Badan Usaha Milik Desa (BUMDes) sangat diperlukan, karena organisasi perusahaan milik desa tidak dapat berfungsi dengan baik tanpa adanya perencanaan. Perencanaan yang dilakukan oleh Badan Usaha Milik Desa (BUMDes) di Desa Tiwoho seperti landasan awal untuk mencapai tujuan yang ingin dicapai dan apa yang perlu dilakukan untuk mencapai tujuan tersebut. Dengan membuat rencana di awal, Anda tidak bisa lepas dari pengetahuan dan pengalaman kepala BUMDes dengan tujuan yang ingin dicapai, karena perencanaan di awal memberikan kontribusi yang sangat penting bagi pencapaian tujuan. Organisasi dengan beberapa program yang direncanakan, hanya satu program yang terbentuk. Indikator perencanaan adalah sebagai berikut:

\section{Penetapan Tujuan}

Menetapkan tujuan yang ingin dicapai oleh Badan Usaha Milik Desa (BUMDes) adalah mewujudkan masyarakat yang sejahtera dan meningkatkan perekonomian desa. Orang-orang terpelajar dapat membawa manfaat sosial bagi masyarakat meskipun tidak menghasilkan keuntungan besar dan bahkan meningkatkan perekonomian kota

\section{Prosedur}

Proses organisasi harus memiliki prosedur yang jelas dan baik untuk pelaksanaan program atau prosedur organisasi lainnya agar organisasi memiliki aturan untuk pelaksanaan program. Dan turut berduka cita kepada Badan Usaha Milik Desa (BUMDes) di Desa Tiwoho, sebaiknya mengikuti langkah prosedur yang telah ditetapkan.

\section{Program}

Didalam organisasi yang baik harus mempunyai program yang baik pula sehingga outputnya bisa di rasakan oleh masyarakat tentunya, program-program tersebut haruslah sesuai dengan keadaan masyarakat, harus sesuai dengan keadaan lingkungan serta sesuai dengan potensi yang ada di desa sekitarnya sehingga program yang dibuat nantinya tidak akan berjalan sia-sia. Program Badan Usaha Milik Desa (BUMDes) saat ini yaitu penyewaan alat pesta dan duka pada Badan Usaha Milik Desa (BUMDes) di Desa Tiwoho. Program ini sudah berjalan tapi masih banyaknya kendala yang terjadi dilapangan, terutama saat penyewaan yang dilakukan oleh masyarakat sering terjadinya keterlambatan dalam pengembalian barang- barang penyewaan bahkan dalam pembayaran penyewaan masih saja ada masyarakat yang terlambat membayar lunas. Ada beberapa program yang juga telah direncanakan oleh Badan Usaha Milik Desa (BUMDes) melalui musyawarah dengan pemerintah desa bahkan masyarakat namun program tersebut belum terealisasi karena tidak cukupnya anggaran yang akan dikeluarkan. Hal ini membuat program Badan Usaha Milik Desa (BUMDes) belum begitu lancar, ini tentunya akan menghambat perkembangan Badan Usaha Milik Desa (BUMDes).

\subsection{Pengorganisasian (Organization)}

Organisasi penting dalam Badan Usaha Milik Desa (BUMDes) karena organisasi dapat menyatukan masyarakat dan membawa mereka ke dalam pekerjaan yang direncanakan sesuai dengan keterampilan dan pengalaman mereka, yang 
dilakukan secara efektif dan efisien, karena pekerjaan dibagi sesuai dengan tugasnya masingmasing. dan fungsi.

Berikut indikator organisasi sebagai berikut:

1. Penempatan Tugas dan Fungsi BadanUsaha Milik Desa (BUMDes)

Pembagian kerja atau tugas harus sesuai dengan keterampilan dan pengalaman masingmasing individu agar pembagian kerja dapat berfungsi secara efisien dan efektif. Dalam Badan Usaha Milik Desa (BUMDes) terdapat tugas dan fungsi yang sesuai dengan bidang keahliannya masing-masing, agar pengurus mengetahui tugas dan peran yang lain, sehingga tidak terjadi tumpang tindih dalam kiprahnya di luar negeri, sehingga fungsinya sebagai pengurus tidak dilakukan. . Keterlibatan manajemen dalam pelaksanaan tugas dan fungsinya merupakan bagian yang tidak terpisahkan dalam mendukung keberhasilan Badan Usaha Milik Desa (BUMDes).

\section{Penetapan Wewenang}

Dalam suatu organisasi yang baik sangat penting untuk memiliki wewenang atau hak untuk melakukan suatu pekerjaan guna mencapai suatu tujuan yang ingin dicapai oleh organisasi tersebut. Penetapan wewenang juga memungkinkan manajemen untuk menjalankan tugasnya dengan baik tanpa adanya intimidasi. dari organisasi internal atau dari organisasi eksternal. Yang dilakukan adalah pengelola memiliki kewenangan untuk melindungi usaha desa dari hal-hal yang dapat mempengaruhi kelangsungan Badan Usaha Milik Desa (BUMDes) dan pemerintah desa, bahkan masyarakat dapat meminta penjelasan atas permasalahan usaha yang ada di desa.

3. Tanggungjawab Badan Usaha Milik Desa (BUMDes)

Tanggungjawab yang dimaksud disini adalah agar pengurus Badan Usaha Milik Desa (BUMDes) mempunyai tanggungjawab dalam melaksanakan tugas yang telah yang diamanahkan kepadanya sehingga tujuan organisasi dapat terlaksana dengan sebaik mungkin. Tanggungjawab yang ada di Badan Usaha Milik Desa (BUMDes) di Desa Tiwoho yaitu bahwa dalam organisasi Badan Usaha Milik Desa (BUMDes) ini mempunyai Struktur organisasi yang didalamnya memuat tanggungjawab masingmasing dalam melaksanakan tugasnya sesuai dengan tanggungjawab atau pun beban yang telah diberikan kepadanya, hal itu telah di tetapkan dalam ADRT maupun dalam peraturan daerah.Namun tanggung jawab yang diberikan tidak dilaksanakan dengan sebaik mungkin, kesadaran dan kepedulian pengurus masih kurang yang terkadang pengurus terlambat atau tidak ikut serta dalam menjalankan tugas.Hal inilah yang harus diperhatikan oleh pengurus untuk lebih bertanggung jawab dalam melaksanakan tugasnya.

\subsection{Penggerakan (Actuating)}

Bergerak atau bertindak adalah tindakan yang bertujuan agar semua anggota berusaha mencapai tujuan sesuai dengan rencana dan upaya organisasi, yaitu membuat orang bekerja sendiri untuk mencapai tujuan secara efektif. tujuan yang telah ditetapkan.

\section{Bimbingan}

Orientasi adalah proses membantu individu dan kelompok memahami diri sendiri dan pekerjaannya sehingga dapat mengerahkan seluruh keterampilannya dan bertindak sesuai dengan peraturan organisasi. Apa saja kekurangan bahkan kendala dalam usaha milik desa (BUMDes).

\section{Saran agar mampu bekerja secara optimal}

Saran adalah pendapat atau saran yang disampaikan kepada Anda untuk dipertimbangkan. Saran-saran tersebut juga berorientasi pada solusi untuk memecahkan masalah yang sedang berlangsung yang bersifat konstruktif, edukatif, objektif, dan konsisten dengan masalah yang dibahas. Yang dimaksud disini adalah atasan menasihati bawahan dalam melaksanakan tugasnya. Tugas dan fungsi agar karyawan atau bawahan dapat bekerja lebih giat lagi.

3. Perintah dalam pelaksanaan tugas

Perintah yang dikeluarkan oleh atasan adalah untuk memastikan kegiatan bawahan, sehingga berbagai tindakan setiap bawahan dikoordinasikan dalam satu arah, itulah tujuan dari Badan Usaha Milik Desa (BUMD). Badan Usaha Milik Sendiri (BUMDes), yaitu melalui proses presidensial, dan kemudian melalui sehingga diberikan perintah dan langsung dilakukan bersama-sama sehingga tidak ada jarak antara pimpinan dan bawahan dan akan lebih terarah dalam melaksanakan tugasnya didalam bekerja.

\subsection{Pengawasan (Controlling)}

Pemantauan langkah-langkah pelaksanaan untuk memantau apakah pergerakan organisasi ini sesuai dengan rencana. Ada tiga fase pemantauan, yaitu menetapkan standar, melakukan penilaian, dan mengambil tindakan korektif.

\section{Menetapkan Alat Ukur Serta Melakukan Penilaian}

Ada kebutuhan untuk menetapkan standar untuk pemantauan sehingga Anda dapat menilai apa yang terjadi di lapangan. Standar ini merupakan peraturan yang harus diterapkan dan dipatuhi karena ketentuan standar yang ada dinilai oleh pihak pengawas dan hasil pengawasan mengetahui apa yang harus dilakukan. Untuk standar pengawasan Badan Usaha Milik Desa (BUMDes), pengawas mengikuti Peraturan Daerah Kabupaten Minahasa Nomor 4 Tahun 2011 yang memuat pengawasan di lingkungan Badan Usaha Milik Desa (BUMDes) tahun berjalan di Badan Usaha Milik Desa (BUMDes) di Desa Tiwoho.

\section{Mengadakan Tindakan Perbaikan}


Untuk dapat melakukan tindakan korektif terlebih dahulu harus dianalisa apa penyebab terjadinya penyimpangan tersebut, terjadinya penyimpangan tersebut harus diketahui terlebih dahulu, jika pihak manajemen mampu menentukan penyebab penyimpangan tersebut dengan pasti, maka tindakan korektifnya harus dilakukan. tindakan harus diambil. Bagaimana kita meminimalkan penyimpangan ini? Kami selalu memperingatkan jika ada penyimpangan dalam organisasi Badan Usaha Milik Desa (BUMDes) di Desa Tiwoho, misalnya sanksi atau peringatan segera diberikan kepada pihak yang berkepentingan agar kesalahan yang sama tidak terjadi lagi

\section{Kesimpulan}

Berdasarkan hasil penelitian yang ada maka penulis menyimpulkan Pengembangan dan Manajemen BUMDES di Desa Tiwoho Kecamatan Wori Kabupaten Minahasa Utara maka diperolehlah kesimpulan sesuai indikator-indikator manajemen yaitu :

1. Dalam mendirikan Badan Usaha Milik Desa (BUMDes)Perencanaan tentunya memegang peran penting sehingga didalam perencanaan ada tujuan usaha, prosedur dan program yang dibentuk. namun pada kenyataannya ada sebagian masyarakat bahkan pemerintah tidak berpegang pada prosedur yang ada. Bahkan dari beberapa program yang dibuat, hanya satu yang dieksekusi/ direalisasikan.

2. Organisasi harus berada di luar struktur organisasi pemerintahan desa, karena BUMDes Desa Tiwoho hanya memiliki tiga pengurus sejak Badan Usaha Milik Desa (BUMDes) didirikan di Desa Tiwoho, terdiri dari kepala perusahaan milik desa , sekretaris dan bendahara yang bertanggungjawab terhadap tugas dan sudah mengetahui fungsinya masingmasing, namun mengakibatkan tidak efektifnya pelaksanaan fungsinya karena kurangnya pengurus.

3. Pada termin penggerakan dengan Badan Usaha Milik Desa (BUMDes) selalu adanya bimbingan, saran \& perintah menurut pengurus Badan Usaha Milik Desa menggunakan menaruh bimbingan, saran supaya sanggup bekerja secara optimal dan menaruh perintah pada aplikasi tugas supaya bisa mencapai tujuan yg sudah ditentukan.

Pada termin supervisi masih kurangnya keterlibatan menurut anggota pengawas sentra menurut pemerintah desa bahkan warga pada mengawasi Badan Usaha Milik Desa Tiwoho dalam termin supervisi masih rendah.

\section{Referensi}

[1] Maryunani, Pembangunan Bumdes dan
Pemberdayaan Pemerintah Desa. Bandung: CV Pustaka Setia., 2008.

[2] Seyadi, BUMDes Sebagai Alternatif Lembaga Keuangan Desa. Yogyakarta: UPP STM YKPN, 2003.

[3] T. P. D. Undang-Undang No 32 Tahun 2004, "Undang-Undang No 32 Tahun 2004 Tentang Pemerintah Daerah," Dpr, 2004.

[4] S. B. Kairupan and J. Mantiri, "Openness of Public Information in the Management of Village Funds in North Minahasa Regency," 2020.

[5] Anom Surya Putra, Badan Usaha Milik Desa(Spirit Usaha Kolektif Desa). 2015.

[6] "Nomor 47 Tahun 2016 tentang Administrasi Pemerintahan Desa." 2016.

[7] A. Paramita and L. Kristiana, "Teknik Focus Group Discussion dalam Penelitian Kualitatif," Tek. Focus Gr. Discuss. dalam Penelit. Kualitatif, 2013.

[8] Y. Afiyanti, "Focus Group Discussion (Diskusi Kelompok Terfokus) sebagai Metode Pengumpulan Data Penelitian Kualitatif," J. Keperawatan Indones., 2008. 